\title{
PENGARUH AROMATERAPI LAVENDER TERHADAP PENURUNAN INTENSITAS NYERI PASIEN PASKA OPERASI SECTIO CAESAREA
}

\author{
Mutia Anwar*, Titi Astuti*, Merah Bangsawan* \\ * Jurusan Keperawatan Poltekkes Tanjungkarang
}

\begin{abstract}
Persalinan sectio caesarea memiliki nyeri lebih tinggi sekitar 27,3\% dibandingkan dengan persalinan normal yang hanya sekitar 9\% (Pratiwi dkk, 2012). Terdapat alternatif dalam penanganan nyeri dengan nonfarmakologi berupa teknik relaksasi pernapasan menggunakan aromaterapi lavender. Tujuan penelitian ini untuk mengetahui pengaruh teknik relaksasi aromatherapi lavender terhadap penurunan intensitas nyeri pada post operasi sectio caesarea. Metode penelitian Quasi Experiment dengan rancangan non-equivalent control group. Teknik pengambilan sampel accidental sampling, diperoleh sampel 24 responden yang terbagi dalam kelompok intervensi dan kontrol. Pengumpulan data menggunakan instrument Numerical Rating Scale (NRS). Uji statistik menggunakan Uji Wilcoxon. Hasil penelitian menunjukkan bahwa ada penurunan rasa nyeri pada kelompok intervensi dari 6.92 menjadi 3.83 (skala nyeri ringan) dan didapatkan rata-rata skala nyeri ibu post operasi sectio caesarea sebelum dan sesudah pada kelompok kontrol yaitu 6.92 dan 5.25. Setelah dilakukan Uji Wilcoxon menunjukkan bahwa ada perbedaan yang bermakna antara kelompok kontrol dan kelompok intervensi sebelum dan sesudah dilakukan teknik relaksasi aromatherapi lavender terhadap penurunan intensitas nyeri pada post operasi sectio caesarea dengan $\mathrm{p}$ value 0.000 ( $\mathrm{p}$ value $<0.05$ ). Peneliti menyarankan agar pihak rumah sakit perlu mempertimbangkan agar perawat maupun bidan dapat mengaplikasikan pemberian aromatherapi sebagai terapi komplementer untuk menurunkan nyeri post sectio caesarea sesuai keadaan pasien dan SOP yang ada.
\end{abstract}

Kata Kunci: nyeri, sectio caesaria, aromatherapy, lavender

\section{LATAR BELAKANG}

Persalinan dapat dilakukan dengan dua cara yaitu persalinan secara normal atau spontan (lahir melalui vagina) dan persalinan abnormal atau persalinan dengan bantuan suatu prosedur seperti Sectio Caesarea. Pada proses sectio caesarea dilakukan tindakan pembedahan, berupa irisan di perut ibu (laparatomi) dan rahim (histerektomi) untuk mengeluarkan bayi (Abasi, 2015 dalam Utami, 2016).

Data World Health Organization (WHO) tahun 2015 selama hampir 30 tahun tingkat persalinan dengan sectio caesarea menjadi $10 \%$ sampai $15 \%$ dari semua proses persalinan di Negara-negara berkembang.

Berdasarkan Survey Demografi dan Kesehatan Indonesia (SDKI) 2012, angka kejadian Sectio Caesarea di Indonesia 921.000 dari 4.039.000 persalinan atau $22,8 \%$ dari seluruh persalinan. Berdasarkan hasil data RISKESDAS tahun
2013, angka ibu melahirkan dengan sectio caesarea di Indonesia 9,8\% dengan proporsi tertinggi di DKI Jakarta 19,9\% dan terendah di Sulawesi Tenggara 3,3\%.

Menurut RISKESDAS tahun 2013 tingkat pesalinan sectio caesarea di Indonesia sudah melewati batas maksimal standar WHO 5-15\%. Tingkat persalinan sectio caesarea di Indonesia 15,3\% sampel dari $20.591 \mathrm{ibu}$ yang melahirkan dalam kurun waktu 5 tahun terakhir yang di survey dari 33 provinsi. Gambaran adanya faktor resiko ibu saat melahirkan atau di operasi caesarea adalah 13,4 \% karena ketuban pecah dini, 5,49\% karena Preeklampsia, 5,14\% karena Perdarahan, 4,40\% Kelainan letak Janin, 4,25\% karena jalan lahir tertutup, 2,3\% karena ruptur uteri.

Angka persalinan sectio caesarea di provinsi Lampung tahun 2013 menurut hasil RISKESDAS sekitar 4,5\%, angka kejadian sectio caesarea di Kota Bandar Lampung pada tahun 2012 adalah 3.401 
dari 170.000 persalinan (20\%) dari seluruh persalinan.

Di RSUD Dr. H Abdul Moeloek Provinsi Lampung terdapat ibu post partum dengan persalinan sectio caesarea di RSUD Dr. H Abdul Moeloek Provinsi Lampung tahun 2012 yaitu 581 orang. Pada tahun 2013 yaitu 722 orang. Pada tahun 2014 yang berjumlah 320 orang dengan rata-rata perbulan 30 orang $(9,09 \%)$. Dari hasil rekam medik terdapat gambaran adanya faktor resiko ibu saat melahirkan atau dioperasi caesar dalam klasifikasi 13,4\%, karena Preeklamsi Berat, 5,49\%, kelainan letak, 5,14\% karena plasenta previa, dan $4,40 \%$ karena partus tak maju.

Dari hasil beberapa penelitian tentang melahirkan melaui operasi Sectio Caesarea menunjukan bahwa melahirkan secara sectio caesarea akan memerlukan waktu penyembuhan luka uterus/rahim yang lebih lama dari pada persalinan normal. Selama luka belum benar-benar sembuh, rasa nyeri bisa saja timbul pada luka tersebut. Bahkan menurut pengakuan para ibu yang melahirkan bayinya menggunakan prosedur operasi, rasa nyeri memang kerap terasa sampai beberapa hari setelah operasi (Maryunani, 2010).

Persalinan sectio caesarea memiliki nyeri lebih tinggi sekitar 27,3\% dibandingkan dengan persalinan normal yang hanya sekitar 9\%. Rasa nyeri meningkat pada hari pertama post operasi sectio caesarea. Secara psikologis tindakan sectio caesarea berdampak terhadap rasa takut dan cemas terhadap nyeri yang dirasakan setelah analgetik hilang (Pratiwi dkk, 2012 dalam Utami, 2016).

Penanganan yang sering digunakan untuk menurunkan nyeri post Sectio Caesarea berupa penanganan farmakologi. Pengendalian nyeri secara farmakologi efektif untuk nyeri sedang dan berat. Namun demikian pemberian farmakologi tidak bertujuan untuk meningkatkan kemampuan klien sendiri untuk mengontrol nyerinya (Van Kooten, 1999; Anggorowati dkk., 2007 dalam Swandari, 2014). Sehingga dibutuhkan kombinasi farmakologi untuk mengontrol nyeri dengan non farmakologi agar sensasi nyeri dapat berkurang serta masa pemulihan tidak memanjang (Bobak, 2004 dalam Swandari, 2014).

Manajemen nonfarmakologi yang sering diberikan antara lain yaitu dengan meditasi, latihan autogenic, latihan relaksasi progresif, guided imagery, nafas ritmik, operant conditioning, biofeedback, membina hubungan terapeutik, sentuhan terapeutik, stimulus kutaneus, hipnosis, musik, accupresure, aromatherapi (Andarmoyo, 2013).

Menurut Dr. Alan Huck (Neurology Psikiater dan Direktur Pusat Penelitian Bau dan Rasa), aroma berpengaruh langsung terhadap otak manusia, mirip narkotika. Hidung memiliki kemampuan untuk membedakan lebih dari 100.000 bau yang berbeda yang sangat berpengaruh pada otak yang berkaitan dengan suasana hati, emosi, ingatan, dan pembelajaran. Dengan menghirup aroma lavender maka akan meningkatkan gelombang-gelombang alfa di dalam otak dan gelombang inilah yang membantu kita untuk merasa rileks (Simkin, 2008 dalam Swandari, 2014). Hal ini terjadi karena aromatherapi mampu memberikan sensasi yang menenangkan diri dan otak, serta stress yang dirasakan (Laila 2011 dalam Swandari, 2014).

Menurut penelitian Khasani \& Amriyah (2012), tentang Pengaruh Aromaterapi Terhadap Nyeri Pada Pasien Post Operasi Sectio Caesarea di RSUD Kajen Kabupaten Pekalongan. Berdasarkan hasil penelitian menunjukkan bahwa ada pengaruh yang signifikan pemberian aromaterapi terhadap nyeri pada pasien post operasi sectio caesara di RSUD Kajen Kabupaten Pekalongan dengan $\rho$ value sebesar $0,001<0,05$.

Berdasarkan hasil pre-survey peneliti pada bulan januari 2017, di RSUD Dr. H. Abdul Moeloek Provinsi Lampung terdapat ibu post partum dengan persalinan Sectio Caesarea di RSUD Dr. H. Abdul Moeloek Provinsi Lampung tahun 2016 yaitu 309 orang. Dari hasil rekam medik terdapat gambaran adanya faktor resiko ibu saat melahirkan atau 
dioperasi caesar dalam klasifikasi 0,62\% karena letak melintang, 4,97 karena palsenta previa, $17,93 \%$ karena preeklamsi, dan $15,98 \%$ karena partus lama.

Hasil wawancara (pre-survey) di dapatkan data dari ibu pasca sectio caesarea, ibu mengatakan nyeri mulai terasa saat obat bius (anestesi) hilang, nyeri timbul saat bergerak, nyeri terasa seperti tersayat-sayat, tertusuk-tusuk, nyeri dirasakan di daerah luka insisi. Ibu mengatakan untuk mengurangi rasa nyeri dengan cara beristirahat dan melakukan tarik napas dalam yang sudah diajarkan oleh bidan. Hasil wawancara peneliti pada bidan di ruang delima untuk penanganan nyeri pada pasien post operasi sectio caesarea diberikan obat sub suprafenid / 8 jam atau analgetik Ketorolac Thromethanine 30mg dalam Ringer Laktat $500 \mathrm{mg} / 8 \mathrm{jam}$. Selain obat analgetik, diajarkan mobilisasi untuk mempercepat penyembuhan luka insisi.

\section{METODE}

Jenis penelitian ini adalah penelitian kuantitatif dengan desain eksperimen semu (quasy experiment design) yang diperluas dengan rancangan non-equivalent control group.

Populasi dalam penelitian adalah ibu post operasi Sectio Caesarea di Ruang Delima RSUD Dr. H. Abdul Moeloek Provinsi Lampung sejumlah 309 orang pasien dengan hasil ratarata tiap bulan sejumlah 26 orang pasien.

Besar sampel dalam penelitian ini ditentukan berdasarkan rumus analitik numerik tidak berpasangan dengan menggunakan penelitian terkait sebelumnya. Berdasarkan perhitungan yang telah dilakukan, diperoleh sampel sebesar 11 orang, dan jumlah responden yang digunakan dalam penelitian ini sejumlah 12 responden untuk masing-masing kelompok.
Teknik sampling yang digunakan pada penelitian ini adalah tehnik nonrondom sampling (sampel tidak acak). Teknik non rondom merupakan teknik pengambilan sampel dari populasi dimana setiap anggota populasi tidak mempunyai kesempatan yang sama untuk diambil sebagai sampel. Penelitian ini menggunakan accidental sampling. Peneliti pada penelitian ini hanya akan mengambil sampel yang termasuk dalam kriteria inklusi dan eksklusi yang telah ditetapkan oleh peneliti.

Instrumen pengumpulan data dalam penelitian ini dilakukan dengan menggunakan alat ukur tingkat nyeri yang dalam penggunaannya dengan observasi. Alat ukur yang digunakan peneliti dalam mengukur intensitas nyeri merujuk pada tingkat nyeri dengan alat ukur (instrumen) Numerical Rating Scale dengan skala nyeri 0-10 untuk menentukan tingkat akhir nyeri. Pengkajian nyeri dilakukan sebelum dan setelah diberikan aromatherapi lavender pada kelompok perlakuan dan kelompok kontrol. Uji statistik menggunakan Uji Mann-Withney.

\section{HASIL}

\section{Analisis Univariat}

Tabel 1: Distribusi Rata-Rata Nyeri Sebelum dan Sesudah pada Kelompok Kontrol

\begin{tabular}{rcccc}
\hline Nyeri & Mean & Med & SD & Min-Max \\
\hline Sebelum & 6.92 & 7.00 & 0.793 & $6-8$ \\
\hline Sesudah & 5.25 & 5.00 & 0.965 & $4-7$ \\
\hline
\end{tabular}

Berdasarkan tabel di atas, distribusi rata-rata nilai skala nyeri ibu post operasi sectio caesarea sebelum pada kelompok kontrol yaitu 6.92 dengan standar deviasi 0.793 , distribusi rata-rata nilai skala nyeri sesudah pada kelompok kontrol yaitu 5.25 dengan standar deviasi 0.965 . 
Tabel 2: Distribusi Rata-Rata Nyeri Sebelum dan Sesudah pada Kelompok Intervensi

\begin{tabular}{rcccc}
\hline Nyeri & Mean & Med & SD & Min-Max \\
\hline Sebelum & 6.92 & 7.00 & 0.793 & $6-8$ \\
\hline Sesudah & 3.83 & 4.00 & 0.835 & $3-5$ \\
\hline
\end{tabular}

Berdasarkan tabel di atas, distribusi rata-rata nilai skala nyeri ibu post operasi sectio caesarea sebelum diberikan teknik relaksasi aromatherapi lavender pada kelompok intervensi yaitu 6.92 dengan standar deviasi 0.793, distribusi rata-rata nilai skala nyeri ibu post operasi sectio caesarea sesudah diberikan intervensi aromatherapi lavender yaitu 3.83 dengan standar deviasi 0.835 .

\section{Analisis Bivariat}

Tabel 5: Hasil Uji Analisis Selisih Nyeri Sebelum dan Sesudah pada Kelompok Kontrol dan Kelompok Intervensi

\begin{tabular}{lcccc}
\hline \multirow{2}{*}{ Kelompok } & \multicolumn{4}{c}{ Nyeri paska Sectio Caesarea } \\
\cline { 2 - 5 } & Mean & $S D$ & $\mathrm{Z}$ & p-value \\
\hline Kontrol & 1.67 & 0.492 & -4.160 & 0.000 \\
\hline Intervensi & 3.09 & 0.515 & & \\
\hline
\end{tabular}

Tabel di atas menunjukkan rata-rata selisih nyeri kelompok kontrol sebesar 1.67 dengan standar devisasi 0.492 dan kelompok intervensi sebesar 3.09 dengan standar devisasi 0.515. Analisis uji non parametik dengan menggunakan MannWhitney didapatkan hasil $\rho$ value 0.000 ( $\rho$ value $0.000<\alpha$ 0.05), maka dapat disimpulkan bahwa adanya pengaruh pemberian teknik relaksasi aromatherapi lavender terhadap penurunan intensitas nyeri post operasi sectio caesarea.

\section{PEMBAHASAN}

\section{Nyeri pada kelompok control}

Hasil penelitian menggambarkan rata-rata nilai skala nyeri ibu post operasi sectio caesarea sebelum pada kelompok kontrol yaitu 6.92 dengan standar deviasi
0.793, sedangkan rata-rata nilai skala nyeri sesudah pada kelompok kontrol yaitu 5.25 dengan standar deviasi 0.965 . Secara teori nyeri yang dihasilkan dari operasi sectio caesarea adalah akibat luka sayatan yang tentunya akan menembus kulit, otot, rahim beserta seluruh persyarafan yang dilewatinya. Luka pada lapisan organ tubuh yang berbeda akan menghasilkan nyeri yang berbeda (Sari, 2013). Nyeri merupakan suatu kondisi yang lebih dari sekedar sensasi tunggal yang disebabkan oleh stimulus tertentu (Potter \& Perry, 2006).

Hal ini sesuai dengan pernyataan di dalam Asmadi (2009) dimana nyeri merupakan sensasi yang rumit, unik, universal dan bersifat individual karena respon individu terhadap sensasi nyeri beragam dan tidak bisa disamakan satu dengan yang lainnya. Hal tersebut menjadi dasar bagi perawat dalam mengatasi nyeri pada klien.

Hasil penelitian skala nyeri sesudah pada kelompok kontrol terjadi penurunan dari rerata 6.92 menjadi 5.25, dan dengan min-max 4-7. Dapat dilihat bahwa ratarata intensitas nyeri pada ibu post operasi section caesarea dapat dikategorikan nyeri sedang, dan terdapat responden yang masih merasakan nyeri yang dikategorikan berat. Ini menunjukkan bahwa klien masih merasakan nyeri yang berat meskipun diberikan terapi farmakologis. Hal ini karena klien memfokuskan semua perhatiannya pada nyeri yang dirasakan (Smeltzer \& Bare, 2002).

Dalam pengendalian nyeri secara farmakologi efektif untuk nyeri sedang dan berat. Namun demikian pemberian farmakologi tidak bertujuan untuk meningkatkan kemampuan klien sendiri untuk mengontrol nyerinya (Van Kooten, 1999; Swandari, 2014). Sehingga dibutuhkan kombinasi farmakologi untuk mengontrol nyeri dengan non farmakologi agar sensasi nyeri dapat berkurang serta masa pemulihan tidak memanjang (Bobak, 2004 dalam Swandari, 2014). 


\section{Nyeri pada kelompok intervensi}

Hasil penelitian pada kelompok intervensi menggambarkan rata-rata nilai skala sesudah pemberian aromatherapi lavender mengalami penurunan dari rerata 6.92 menjadi 3.83, dan dengan min-max 35. Dapat dilihat bahwa rata-rata intensitas nyeri pada ibu post operasi section caesarea dapat dikategorikan nyeri sedang dan nyeri ringan. Nyeri ringan adalah nyeri tidak mengganggu aktivitas mobilisasi atau secara obyektif pasien dapat berkomunikasi dengan baik, tindakan manual dirasa sangat membantu. Hal ini terjadi karena ibu post operasi sectio caesarea dapat mempraktekkan teknik relaksasi aromatherapi lavender dengan benar dalam lama waktu latihan kurang lebih 15 menit, dan responden tidak memfokuskan semua perhatiannya pada nyeri yang dirasakan.

Menurut Dr.Alan Huck (Neurology Psikiater dan Direktur Pusat Penelitian Bau dan Rasa), aroma berpengaruh langsung terhadap otak manusia, mirip narkotika (Swandari, 2014). Aromaterapi yang digunakan melalui cara inhalasi atau dihirup akan masuk ke sistem limbic dimana nantinya aroma akan diproses sehingga kita dapat mencium baunya. Pada saat kita menghirup suatu aroma, komponen kimianya akan masuk ke bulbus olfactory, kemudian ke limbic sistem pada otak. Hal ini akan merangsang memori dan respon emosional. Hipotalamus berperan sebagai relay dan regulator, memunculkan pesan-pesan yang harus diterima kemudian diubah menjadi tindakan yang berupa pelepasan senyawa elektrokimia berupa zat endorphin dan serotonin, sehingga berpengaruh langsung pada organ penciuman dan diopersepsikan oleh otak untuk memberikan reaksi yang membuat perubahan fisiologis pada tubuh, pikiran, jiwa, dan menghasilkan efek menenangkan pada tubuh sehingga dapat mengurangi nyeri (Dewi, dkk.2013). Hal ini sesuai dengan pernyataan beberapa responden yang ketika mencium atau menghirup aromatherapi lavender yang diteteskan pada tissue, responden merasakan ketenangan, dikarenakan aromanya yang harum dan segar.

Menurut peneliti penurunan skala nyeri sesudah dilakukan teknik relaksasi aromatherapi lavender juga dipengaruhi karena aromatherapi lavender mempunyai peranan penting dalam mengurangi rasa nyeri. Hal ini sesuai dengan Ross (2006, h.106) menyatakan bahwa aromatherapi yang digunakan melalui penciuman dapat langsung dibawa lewat syaraf alat penciuman ke hypotalamus atau area limbic dari otak, memori dan emosi sehingga dapat mengurangi rasa nyeri. Nyeri dapat diatasi dengan penatalaksanaan nyeri yaitu cara meringankan nyeri atau mengurangi nyeri sampai tingkat kenyamanan yang dapat diterima klien.

\section{Pengaruh aromatherapi lavender pada intensitas nyeri pasien post operasi sectio caesarea}

Berdasarkan hasil penelitian yang telah dilakukan dengan menggunakan uji Mann-Whitney diperoleh hasil p-value $(0,000)<\alpha(0,05)$, yang berarti $H_{0}$ ditolak, sehingga dapat disimpulkan bahwa pemberian aromatherapi lavender berpengaruh terhadap penurunan intensitas nyeri post operasi sectio caesarea di.

Sesuai dengan teori gate control yang dikemukakan oleh Melzack dan Wall bahwa impuls nyeri dihambat saat sebuah pertahanan ditutup, sehingga dapat menurunkan intensitas nyeri yang dirasakan. Hal ini menyatakan bahwa aromatherapi akan merangsang keluarnya hormone enfekalin, serotonin dan endorphin. Enfekalin dianggap dapat menimbulkan hambatan presinaptik dan hambatan pasca sinaptik pada serabutserabut nyeri tipe $\mathrm{C}$ dan tipe delta $\mathrm{A}$ dimana mereka bersinaps di komu dorsalis. Proses tersebut mencapai inhibisi dengan penghambatan saluran kalsium. Penghambatan nyeri tersebut yaitu dengan memblok reseptor nyeri sehingga nyeri tidak dikirim ke korteks selebri dan selanjutnya akan menurunkan persepsi nyeri. Hal ini sejalan dengan penelitian yang dilakukan oleh (Akbar, dkk, 2014; 
Abasi, 2015) bahwa penggunaan aromaterapi secara inhalasi dapat merangsang pengeluaran endorphin efektif menurunkan nyeri ibu post partum dengan $p$ value $(0,000)<\alpha(0,05)$.

Hasil penelitian ini didukung oleh penelitian yang sudah dilakukan Kim pada tahun 2007 menyebutkan bahwa penggunaan terapi aroma untuk perawatan post operasi anastesi dengan pemakaian aromatherapi lavender memiliki pengaruh yang signifikan dan lebih efektif dibandingkan dengan pemakaian sadatif. Selain itu, hasil yang diperoleh mengenai kegiatan penalitian ini yaitu pemakaian terapi aroma lavender lebih efektif dalam proses penurunan nyeri dibandingkan dengan pemakaian dengan pemakaian analgesik $(p$-value $=0.007)$. Kedua jenis metode tersebut dapat dikombinasikan satu sama lain sehingga lebih cepat dalam proses penurunan tingkat intensitas nyeri. Namun demikian, metode non farmakologi memiliki kelebihan yaitu proses pelaksanaannya relatif sederhana, efektif, dan tidak menimbulkan efek merugikan (Potter \& Perry, 2005; Pratiwi, 2012).

Menurut peneliti, jika melihat dari analisa bivariat baik pada kelompok kontrol maupun kelompok intervensi dan didukung oleh teori serta pembahasan mengenai hasil peneliti-peneliti sebelumnya dapat disimpulkan terdapat pengaruh teknik relaksasi aromatherapi lavender terhadap penurunan intensitas nyeri pada post operasi sectio caesarea. Pemberian aromatherapi lavender merupakan salah satu dari terapi komplementer berupa latihan teknik relaksasi pernapasan. Prinsip dasar teori penurunan nyeri oleh teknik relaksasi pernapasan menggunkan aromatherapi lavender adalah teori gate control yang terletak pada fisiologis sistem otonom. Tarik napas dalam dapat memberikan individu kontrol diri ketika terjadi rasa ketidaknyamanan atau cemas, stress fisik dan emosi yang menyebabkan nyeri meningkat, sehingga mendekatkan hubungan terapeutik perawat dan klien. Pemberian aromatherapi lavender direkomendasikan agar dapat diterapkan dan di kombinasikan dengan terapi komplementer lain sebagai terapi pendamping atau sebagai bagian dari intervensi keperawatan dalam pemberian asuhan keperawatan pada pasien yang mengalami nyeri pasca operasi.

\section{KESIMPULAN}

Berdasarkan hasil penelitian dapat disimpulkan bahwa rata-rata skala nyeri pada ibu paska operasi sectio caesarea sebelum dan sesudah pada kelompok kontrol yaitu 6.92 dan 5.25, sedangkan pada kelompok kelompok intervensi yaitu 6.92 dan 3.83 .

Hasil analisis statistik lebih lanjut menggunakan Uji Mann-Withney dapat disimpulkan bahwa ada perbedaan yang bermakna antara kelompok kontrol dan kelompok intervensi sebelum dan sesudah dilakukan teknik relaksasi aromatherapi lavender terhadap penurunan intensitas nyeri pada post operasi sectio caesarea dengan $p$ value 0.000 ( $p$ value < 0.05 ). Hal ini berarti bahwa terdapat pengaruh aromaterapi lavender terhadap nyeri pada pasien paska operasi sectio caesaria.

Berdasarkan kesimpulan tersebut peneliti menyarankan agar pihak rumah sakit perlu mempertimbangkan agar perawat maupun bidan dapat mengaplikasikan pemberian aromatherapi sebagai terapi komplementer untuk menurunkan nyeri post sectio caesarea sesuai keadaan pasien dan SOP yang ada.

\section{DAFTAR PUSTAKA}

Andarmoyo, S. 2013. Konsep \& Proses Keperawatan Nyeri. Jogyakarta: ArRuzz Media.

Asmadi. 2009. Teknik Prosedural Keperawatan Konsep Aplikasi Kebutuhan Dasar Klien. Jakarta: Salemba Medika.

Dewi, Iga Prima, dkk. 2013. Aromaterapi Lavender Sebagai Media Relaksasi. Universitas Udayana: Bagian Farmasi Fakultas Kedokteran. 
Jurnal Farmasi Fakultas Kedokteran Universitas Udayana Bali.

Khasani, dkk. 2012. Pengaruh Aromaterapi Terhadap Nyeri Pada Pasien Post Operasi Sectio Caesarea Di RSUD Kajen Kabupaten Pekalongan

Kozier, Erb, Berman, \& Synder. 2010. Buku Ajar Fundamental Keperawatan ; Konsep, Proses, \& Praktik Ed. 7 Vol. 2. Jakarta: EGC.

Maryunani, 2010. Nyeri dalam Persalinan. Jakarta: Trans Info Medika.

Potter \& Perry. 2006. Buku Ajar Fundamental Keperawatan. Jakarta: EGC.

Pratiwi, dkk. 2012. Penurunan Intensitas Nyeri Akibat Luka Post Sectio Caesarea Setelah Dilakukan Latihan
Teknik Relaksasi Pernapasan Menggunakan Aromaterapi Lavender di Rumah Sakit Al Islam Bandung. Jurnal KeperawatanUniversitas Padjajaran Bandung.

Swandari, P. 2014. Perbedaan Tingkat Nyeri Sebelum Dan Sesudah Pemberian Aromatherapi Lavender Pada Ibu Post Sectio Caesarea di RSUD Ambarawa. Jurnal Kebidanan STIKES Ngudi Waluyo Ungaran.

Utami, S. 2016. Efektivitas Aromaterapi Bitter Orange Terhadap Nyeri Post Partum Sectio Caesarea di RSUD Arifin Achmad Pekanbaru. http://journal.unnes.ac.id/sju/index.p hp/ujph. (diakses pada Oktober 2016). 